Article

\title{
American Chestnut Growth and Survival Five Years after Planting in Two Silvicultural Treatments in the Southern Appalachians, USA
}

\author{
Stacy Clark $^{1, *}$, Henry McNab ${ }^{2}$, David Loftis ${ }^{2}$ and Stanley Zarnoch ${ }^{3}$
}

1 Southern Research Station, United States Department of Agriculture Forest Service, 2431 Joe Johnson Drive, Room 274, Knoxville, TN 37996, USA

2 Southern Research Station, United States Department of Agriculture Forest Service, 1577 Brevard Rd., Asheville, NC 28806, USA; E-Mails: hmcnab@fs.fed.us (H.M.); davidloftis@bellsouth.net (D.L.)

3 Southern Research Station, United States Department of Agriculture Forest Service, 200 W.T. Weaver Blvd., Asheville, NC 28804, USA; E-Mail: szarnoch@fs.fed.us

* Author to whom correspondence should be addressed; E-Mail: stacyclark@fs.fed.us; Tel.: +1-865-974-0932; Fax: +1-865-974-4714.

Received: 20 August 2012; in revised form: 26 October 2012 / Accepted: 31 October 2012 / Published: 9 November 2012

\begin{abstract}
The ability to restore American chestnut (Castanea dentata) through the planting of blight-resistant (Cryphonectria parasitica) trees is currently being tested. Forest-based research on the species' silvicultural requirements and chestnut blight development are lacking. Pure American chestnut seedlings were planted in a two-age shelterwood forest with low residual basal area and in a midstory-removal treatment with high residual basal area. Survival did not differ between silvicultural treatments and averaged 67 percent across both treatments by the fifth year. Trees in the two-age shelterwood were $2.36 \mathrm{~m}$ and $16.8 \mathrm{~mm}$ larger in height and ground-line diameter, respectively, compared to trees in the midstory-removal by the fifth growing season. Blight occurrence was not affected by silvicultural treatment. Exploratory analyses indicated that seedling grading at planting and keeping trees free-to-grow through competition control would have resulted in a two-year gain in height and GLD growth in the two-age shelterwood treatment. The two-age shelterwood represented the most efficacious prescription for chestnut restoration, but the midstory-removal prescription may offer a reasonable alternative in areas where harvesting must be delayed.
\end{abstract}


Keywords: American chestnut; artificial regeneration; forest management; midstory-removal; restoration; shelterwood harvesting

\section{Introduction}

The American chestnut (Castanea dentata Marsh. Borkh.) was an abundant and important tree species in eastern North American forests for thousands of years until the 20th century [1]. At its greatest distribution, the American chestnut constituted one-fourth to one-half of the canopy trees in its native range $[2,3]$. In the early $1900 \mathrm{~s}$, the American chestnut provided more than 25 percent of all timber harvested in the southern Appalachians [4]. The species was described as important for forest management in Tennessee [5] and a "promising tree" for artificial regeneration in the early 1900s [6].

The chestnut blight (Cryphonectria parasitica Murr. Barr) was introduced in New York ca. the early 1900s, probably through imported Japanese chestnut (C. crenata Siebold and Zucc.) nut cultivars [7], and the American chestnut was ecologically extirpated within a few decades. The species was able to persist from remnant root systems as understory sprouts that infrequently live long enough to flower and bear fruit [8].

To date, American chestnut restoration has largely focused on producing a blight-resistant tree through a backcross breeding technique with resistant Asian parental species, [9,10]. Successful restoration will also require testing and development of silvicultural prescriptions and cultural field practices for planting and growing blight-resistant American chestnut seedlings once they become available [11,12]. Seedling growth response and resistance to blight is affected not only by genetic breeding, but also by site conditions and forest cultural practices [13].

After decades of blight-resistance and hypovirulence research conducted by several programs, chestnut reintroduction trials are underway $[9,13,14]$. A limited number of putative blight-resistant seedlings developed through the backcross breeding program of The American Chestnut Foundation have been planted in National Forests in 2009, 2010 and 2011 [14]. As breeding programs become more refined through field testing, the goal is to release chestnuts for widespread restoration efforts on public and private lands. Unfortunately, little empirical research on protocols needed to artificially regenerate chestnut has been conducted, largely due to the limited availability of experimental material.

Pure American chestnut seedlings respond positively to increased light in the field and under controlled environmental conditions [15-18]. Chestnut seedlings had similar or better survival in shaded conditions compared to openings receiving full sunlight [15,19-21]. Based on this limited amount of empirical research, chestnut likely has silvicultural requirements similar to oak (Quercus) species in that the seedlings can persist in the absence of disturbance, but growth is stimulated by increased light [12,22]. A commercial shelterwood harvest has been shown to be an acceptable regeneration method for chestnut due to the species' positive response to increased light levels $[15,16]$ that will occur following canopy removal, cf. [23]. However, high-light conditions and intense vegetation competition associated with low residual basal area harvests may also favor blight development, cf. [21]. In contrast, the relatively low-light levels and high canopy cover that exist following a non-commercial midstory-removal $[23,24]$ several years prior to a commercial harvest 
might also be an adequate prescription to promote a competitive advantage over shade-intolerant species [15,25], while also limiting blight infection [21].

Prior to the arrival of blight in eastern North America, chestnut dominated a wide range of forest site types (3). Incidence of blight was related with topo-edaphic conditions, including elevation [13]. Chestnuts growing on xeric sites or at high elevations appear to be most susceptible to blight damage $[13,26]$. Interactions between forest management practices and site quality need further testing to refine protocols for future American chestnut restoration efforts [12].

To our knowledge, this is one of only a few studies within the natural range of the species that has empirically tested the response of American chestnut planted under two contrasting light regimes created through shelterwood regeneration prescriptions $[15,19,20]$. This research is timely, as the shelterwood regeneration treatment is part of recent United States Department of Agriculture, Forest Service's national forest management plans within the chestnut's range in the southeastern United States [27-29], and is just recently being proposed as a treatment for restoration of blight-resistant chestnuts, once they become available [30].

In this study, we examine survival, growth, and blight development of American chestnut seedlings five years after planting. Our objectives were to quantify differences in survival, height and ground-line diameter growth, and chestnut blight development between two shelterwood regeneration treatments that created contrasting understory light conditions. We also conducted exploratory analysis to test effects of seedling quality at planting, chestnut blight development, and competitive position on subsequent growth and survival.

\section{Methods}

\subsection{Study Site and Experimental Material}

Our study was conducted in the Bent Creek Experimental Forest $\left(35.5^{\circ} \mathrm{N}, 82.625^{\circ} \mathrm{W}\right)$, located in the Southern Appalachian Mountains about $16 \mathrm{~km}$ south of Asheville, NC in Buncombe County. This watershed of 2400 ha ranges in altitude from $600 \mathrm{~m}$ in a broad intermountain basin to $1100 \mathrm{~m}$ along two primary ridges. Annual temperature averages $13{ }^{\circ} \mathrm{C}$; the frost free season averages 157 days. Precipitation averages about $120 \mathrm{~cm}$ annually and is evenly distributed throughout the year. Geologic formations primarily consist of Precambrian gneisses and schists. Soils are generally deep $(>99 \mathrm{~cm}$.), and predominantly acidic $(\mathrm{pH}<5.5)$. Ultisols of the Evard-Cowee complex are common on gentle slopes of lower elevations; Inceptisols of the Tuckasegee-Cullasaja complex are common in coves and steeper mountainous slopes.

Arborescent vegetation on upland sites consists of a high canopy ( $>30 \mathrm{~m})$ of deciduous hardwoods. Dry sites on mid to upper slopes and ridges are occupied primarily by xerophytic oaks: black (Quercus velutina Lam.), chestnut (Q. prinus L.), and scarlet (Q. coccinea Muenchh.). Moist sites, in coves and lower and middle slopes, are usually occupied by mesophytic species, including yellow-poplar (Liriodendron tulipifera L.), sweet birch (Betula lenta L.) and northern red oak (Q. rubra L.). White oak (Q. alba L.) is common in the transition area between dry and moist sites, which includes subxeric to submesic moisture regimes. Red maple (Acer rubrum L.) is common on all sites and typically occurs in the midstory with sourwood [Oxydendrum arboretum L. (DC)], dogwood 
(Cornus florida L.), and blackgum (Nyssa sylvatica Marsh.). Mountain laurel (Kalmia latifolia L.), a tall, evergreen shrub, is common on dry sites.

American chestnut was a predominant species throughout most upland stands of the experimental forest until about 1930, when approximately 80 percent of trees in the region had been infected with the chestnut blight [31]. On southern Appalachian sites similar to those in the experimental forest, Braun [32] reported that canopy stocking of American chestnut had ranged from about 17 percent in moist coves to 82 percent on drier upper slopes. Keever [33], and Woods and Shanks [34] found that chestnut oak, northern red oak, and red maple were the most common species occurring in canopy gaps resulting from mortality of American chestnut.

\subsection{Study Sites and Treatments}

The study was installed in three distinct forest stands, each stand averaged 1.3 ha in size and were not disturbed significantly by humans or by natural disturbances during the past 50 years. The stands represented a range of site quality conditions and a soil moisture gradient from xeric to mesic, with one stand transitional between xeric and mesic (Table 1).

Table 1. Topographic characteristics of the stands.

\begin{tabular}{ccccccc}
\hline $\begin{array}{c}\text { Moisture } \\
\text { regime }\end{array}$ & $\begin{array}{c}\text { Elevation } \\
(\mathbf{m})\end{array}$ & Landform & $\begin{array}{c}\text { Aspect } \\
\text { (degrees) }\end{array}$ & $\begin{array}{c}\text { Steepness } \\
\text { (percent) }\end{array}$ & Surface shape & $\begin{array}{c}\text { Site index for } \boldsymbol{Q} \text {. rubra } \\
\text { (m, base age 50) }\end{array}$ \\
\hline Mesic & 880 & Cove & $45-74$ & $45-74$ & Linear-concave & 26.2 \\
Subxeric & 780 & Slope & $195-282$ & $38-43$ & Linear-convex & 20.1 \\
Xeric & 760 & Ridge & $329-345$ & $39-46$ & Linear-convex & 17.7 \\
\hline
\end{tabular}

Each stand was divided into two approximately equally sized treatment areas and was randomly assigned one of two silvicultural treatments. Two shelterwood regeneration treatments were studied, including a two-age shelterwood harvest, and a midstory-removal treatment. Both treatments represent different stages of an even-aged regeneration system, but result in markedly different light levels to the developing understory [23]. The two-age shelterwood method consists of harvesting or cutting most of the stocking, but leaving residual basal area for the life of the stand [35]. In this study, we left a residual basal area of $2.75 \mathrm{~m}^{2} \cdot \mathrm{ha}^{-1}$ for trees greater than $15 \mathrm{~cm} \mathrm{dbh}$, and remaining merchantable or non-merchantable trees greater than $1.4 \mathrm{~m}$ in height were harvested or cut. In the two-age shelterwood, site preparation treatments included treating cut stumps with 50 percent solution of triclopyr amine with water. All non-merchantable stems (stems approximately 3 to $15 \mathrm{~cm} \mathrm{dbh}$ ) were also cut and herbicide applied to prevent sprouting.

The midstory-removal method is the first stage of a shelterwood regeneration harvest, designed to improve light quantity and quality to the understory to promote oak recruitment until the commercial harvest is conducted [25]. The original stand basal area (for trees $>3 \mathrm{~cm} \mathrm{dbh}$ ) was reduced by 35 percent to $27.5 \mathrm{~m}^{2} \cdot \mathrm{ha}^{-1}$ by treating stems using a hack and squirt herbicide method. Approximately $1 \mathrm{ml}$ of triclopyr was applied to hatchet marks of trees hacked once for every $6 \mathrm{~cm} \mathrm{dbh}$. Only stems in the understory and midstory layers were treated to avoid creating openings in the overstory canopy that could increase light on the forest floor to favor shade-intolerant species. Silvicultural treatments were completed by February 2005. American chestnuts were obtained from The American Chestnut 
Foundation. Nuts were from a Pennsylvania pure American chestnut seed source and were grown for two years at the North Carolina Forest Service's nursery in Goldsboro, NC. Local seed sources of American chestnut would have been preferred for this study, but were not available. In March 2006, trees were lifted as bare-root nursery seedlings. Thirty-three to 37 trees were planted in the center of each silvicultural treatment area using a KBC planting bar on a1.8 by $1.8 \mathrm{~m}$ spacing in April 2006. Three growing seasons after planting (2008), competing vegetation immediately surrounding the planted chestnuts in the two-age shelterwood stands was treated with a steamline method of herbicide application using a 17 percent solution of tricoplyr ester mixed in mineral oil with a 3 percent mixture of an oil carrier.

\subsection{Data Collection}

Height and ground-line diameter (GLD) measurements were taken at planting and in years 1, 2, 3, and 5 after trees entered into dormancy (November through March). Height was measured to the nearest $0.01 \mathrm{~m}$ from the ground line to the tallest terminal bud. Ground-line diameter was measured to the nearest $0.1 \mathrm{~mm}$ using digital calipers. Chestnut blight was identified on the base of the tree as a slightly raised canker or a sunken, discolored area on the stem, and was sometimes accompanied by the appearance of stromata (orange fruiting bodies) on the smooth bark surrounding cankers [36]. Other evidence of blight included bark cracking and fissuring with distinguishable mycelium arranged in buff-colored fans on the inner bark [36]. Chestnut blight was identified on living trees and trees that had been dead for less than one year. In years 2, 3 and 5 in the two-age shelterwood treatment, we documented if the tree was free-to-grow. If a competing understory tree $(<3 \mathrm{~cm} \mathrm{dbh})$ was directly over top of the tallest bud of the chestnut tree, the chestnut seedling was classified as overtopped, otherwise, it was classified as free-to-grow. We did not document free-to-grow status in the midstory-removal treatment because that stand had not yet been harvested and understory competition to planted seedlings was minimal.

\subsection{Statistical Analysis}

We used SAS [37] and an alpha level of five percent for the Type I error rate for all statistical analysis unless otherwise noted. A randomized, complete-block design was used to assign the two silvicultural treatments to the three stands. Silvicultural treatment was a fixed effect, and stand was a random blocking effect in our model. We conducted a repeated measures, linear mixed model analysis of variance (ANOVA) using PROC MIXED with a spatial power SP(POW) covariance structure to analyze absolute height and GLD data where year was the repeated measures variable for each tree [38]. We compared corrected Akaike information criterion (AICc) values for the SP(POW) model with unstructured (UN) and compound symmetry (CS) covariance structures. We determined the SP(POW) structure had the smallest AICc values and was the most parsimonious model for both height and GLD.

We used generalized linear mixed models to test treatment effects on our binomial response variables, chestnut blight and survival. We used PROC GLIMMIX to test if the presence/absence of chestnut blight was affected by silvicultural treatment using the variable year as a split plot factor [38]. We ran PROC GLIMMIX by year to test treatment effects on survival. 
Normality of residuals were tested using the Shapiro-Wilk test for normality for each linear mixed model. Our tests met normality assumptions for the residuals, so no transformations were required. Homogeneity of variance assumptions were tested for each linear mixed model by examining residuals versus predicted values. Unequal variance was added to the model using the REPEATED statement if plots of residuals versus predicted values indicated unequal variance was present in the dataset; degrees of freedom were accordingly adjusted in the unequal variance models using the Kenward-Roger method. A likelihood ratio test was used to test if the unequal variance model was justified. For all models where main effects or interactions were significant, we computed comparisons among the least-squares means using a Bonferroni adjustment, and we used DandA.sas macros [39] to compare treatment means.

For each linear mixed model and generalized linear mixed model, we calculated estimates of the empirical best linear unbiased predictors (EBLUPS) and associated T-tests for the random-effects parameters using the SOLUTION option in the RANDOM statement to determine how trees within each stand differed from the average for the population, which was set to zero. We felt these tests were important because we predicted the random variable, stand, would affect growth and survival due to differences in site quality among stands (Table 1). We did not want to make false inferences from the data by pseudo-replicating the study using each tree as a replicate, and testing stand as a fixed effect in the model. The effects of site quality could only be interpreted using T-tests of the EBLUPS of the random stand effects and their interactions with treatment.

Trees that had developed chestnut blight by year 5 were excluded from the height and GLD ANOVAs because we wanted to extrapolate our results to the chestnut trees being bred for blight resistance that will putatively be resistant to blight but behave like a pure American chestnut [40]. Examination of analysis run on all trees indicated that excluding trees with blight in year 5 would not have changed inferences we gleaned from our analyses.

Exploratory analyses that were not part of the original experimental design were conducted to determine if differences in growth existed between trees with and without chestnut blight and between trees that were and were not free-to-grow. We added the presence/absence of chestnut blight as a treatment effect to the above-mentioned ANOVA model for height to determine effects of chestnut blight and interactions with year and treatment. We used linear mixed model ANOVA with repeated measures to determine if free-to-grow status affected height and GLD growth in the two-age shelterwood stand (we did not assess free-to-grow status in the midstory-removal treatment). We also conducted a post-hoc analysis to determine if seedling size at planting effected subsequent fifth year survival, and height and GLD growth in each year. We first divided seedlings into two groups based on seedling size at planting. Trees with heights greater than $0.56 \mathrm{~cm}$ and GLD greater than $8.8 \mathrm{~mm}$ were placed into a 'Large' seedling size category. All other trees were placed into a 'Small' seedling size category. These categories were based on the overall means of seedling size at the time of planting and resulting in 41 percent of trees categorized in the Large size class and 59 percent categorized in the Small size class. We used the linear mixed model ANOVAs as described above and added the seedling size variable as a split plot variable. In these models, silvicultural treatment was the whole plot factor, and seedling size was the split-plot factor. 


\section{Results}

Survival did not differ between silvicultural treatments for any year $(\mathrm{F}<0.32$, $\mathrm{df}=2, P>0.63)$ and averaged 67 percent across all stands and treatments by the fifth year (Table 2).

Table 2. Least-squares means for percent survival within silvicultural treatments and raw means across treatments with associated standard errors in parenthesis for each year after planting American chestnuts.

\begin{tabular}{cccc}
\hline Year after planting & Two-age shelterwood & MidstoryRemoval & All \\
\hline 1 & $84(8)$ & $87(8)$ & $86(2)$ \\
2 & $78(11)$ & $81(11)$ & $79(3)$ \\
3 & $75(10)$ & $75(11)$ & $75(3)$ \\
5 & $63(11)$ & $72(11)$ & $67(3)$ \\
\hline
\end{tabular}

The highest annual rate of mortality occurred in the first growing season for both treatments. The two-age shelterwood treatment in the subxeric stand had EBLUP with significant T-values for every year, indicating that this experimental unit had lower survival than predicted for the average of the population. In contrast, the two-age shelterwood treatment in the xeric stand had an EBLUP at year 5 of 25, with a significant T-value, indicating this experimental unit had higher survival than the average predicted for the population. No other EBLUPS for stand or stand by treatment interactions for survival were significantly different than zero.

Main effects of treatment $(\mathrm{F}=36.5$, adjusted $\mathrm{df}=3, P=0.01)$, year $(\mathrm{F}=118.0$, adjusted $\mathrm{df}=274$, $P<0.01)$ and their interactions $(\mathrm{F}=91.6$, adjusted $\mathrm{df}=274, P<0.01)$ were significant for height. Similarly, main effects of treatment $(\mathrm{F}=20.2$, adjusted $\mathrm{df}=9, P=0.01)$, year $(\mathrm{F}=116.8$, adjusted $\mathrm{df}=295, P<0.01)$, and their interactions $(\mathrm{F}=47.6$, adjusted $\mathrm{df}=295, P<0.01)$ were significant for GLD. Comparisons among the least-squares means show that differences in planting and first year height and GLD between silvicultural treatments were not significant (Figure 1).

By the second year, trees planted in the two-age shelterwood were $0.50 \mathrm{~m}$ taller in height and $5.8 \mathrm{~mm}$ larger in GLD compared to trees planted in the midstory-removal. At the end of the fifth growing season, trees in the two-age shelterwood were $3.11 \mathrm{~m}$ tall and $30.4 \mathrm{~mm}$ in GLD, which was $2.36 \mathrm{~m}$ taller in height and $16.8 \mathrm{~mm}$ larger in GLD compared to trees in the midstory-removal. Trees in the two-age shelterwood grew $0.51 \mathrm{~m}$ in height and $4.3 \mathrm{~mm}$ in GLD per year on average compared to $0.04 \mathrm{~m}$ in height and $1.0 \mathrm{~mm}$ GLD per year in the midstory-removal treatment. In the midstory-removal treatment, trees grew significantly in GLD from years 2 to 3 and from years 3 to 5 , but did not grow significantly in annual increment before year three. Trees did not grow significantly in annual height growth increment for any year in the midstory-removal treatment. Trees in the two-age shelterwood grew significantly in annual height and GLD increment in every year. Trees in the two-age shelterwood were significantly taller in height and larger in GLD after three growing seasons compared to trees at the end of the fifth year in the midstory-removal treatment. The EBLUPS for each random level were not significantly different than zero for height or GLD, indicating that stand and stand by treatment interaction effects on growth were minimal. 
Figure 1. Height and ground-line diameter with associated standard error bars for five years after planting American chestnuts in two silvicultural treatments. Asterisks, positioned above the two-age shelterwood line, indicate significant differences between the two treatments within a year. Plus signs, positioned above the two-age shelterwood line or below the midstory-removal line, indicate significant differences between that year and the year prior within silvicultural treatment.
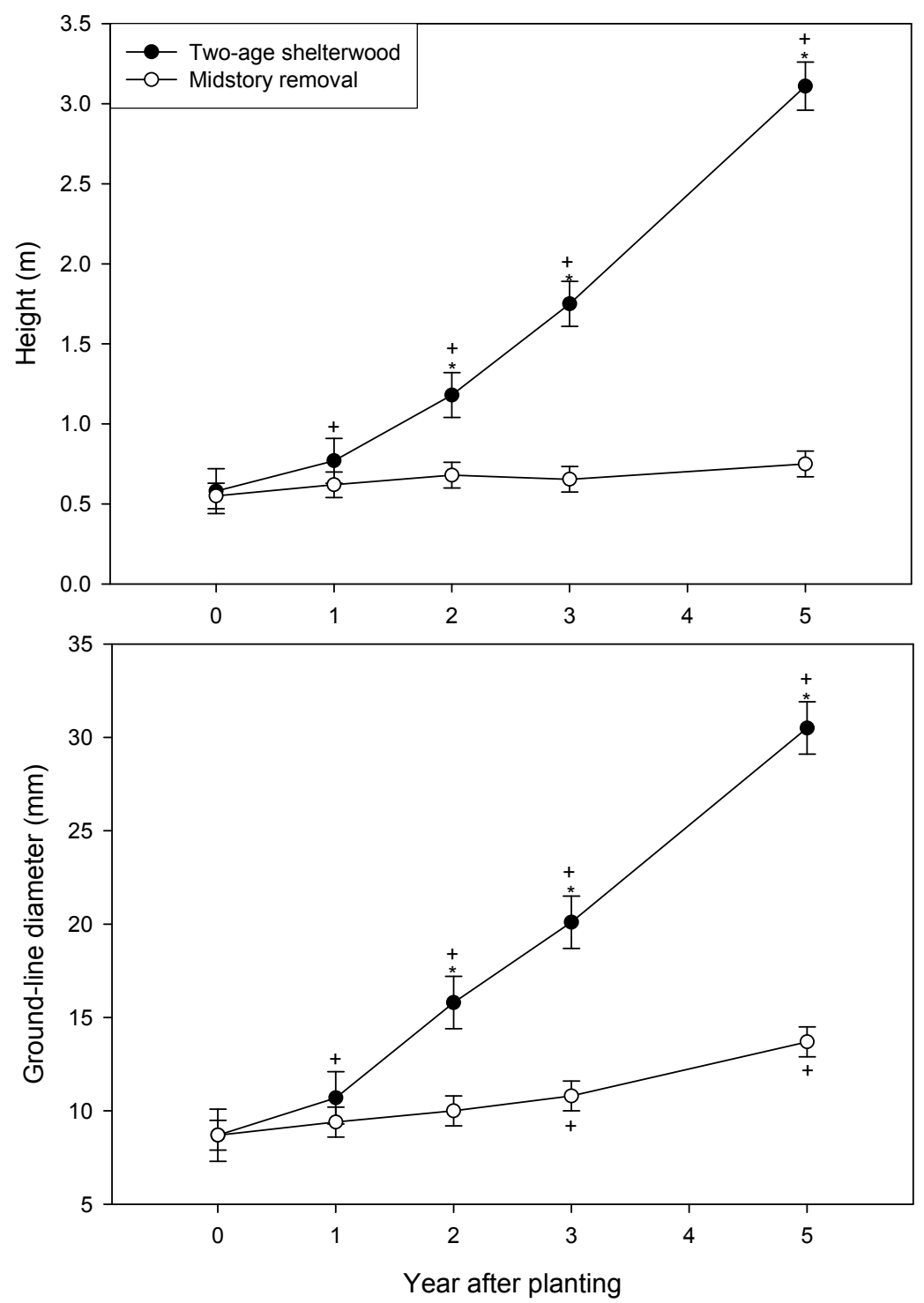

In the post-hoc analysis examining effects of seedling size class at planting on tree growth, size was a significant effect for height $(\mathrm{F}=11.03$, adjusted $\mathrm{df}=60, P=0.01)$ and GLD $(\mathrm{F}=19.8$, adjusted $\mathrm{df}=15, P=0.01)$. Size interactions with treatment $(\mathrm{F}=1.0$, adjusted $\mathrm{df}=60, P=0.32)$ and year ( $\mathrm{F}=1.1$, adjusted $\mathrm{df}=266, P=0.35$ ) were not significant for height. The year by size interaction was significant for GLD $(\mathrm{F}=2.6$, adjusted $\mathrm{df}=288, P=0.04)$. Treatment by size interactions for GLD were not significant $(\mathrm{F}=2.9$, adjusted $\mathrm{df}=15, P=0.11)$. Large size class seedlings were $0.99 \mathrm{~m}$ and 
$12.0 \mathrm{~mm}$ larger in height and GLD compared to Small size class seedlings within the two-age shelterwood treatment for year 5; size class differences were not significant for earlier years in this treatment (Figure 2).

Figure 2. Height and ground-line diameter with associated standard error bars for five years after planting American chestnuts in two silvicultural treatments for two seedling size class groups. Asterisks, positioned above the two-age shelterwood lines or below the midstory-removal lines, indicate significant differences between the two size classes within year and silvicultural treatment.
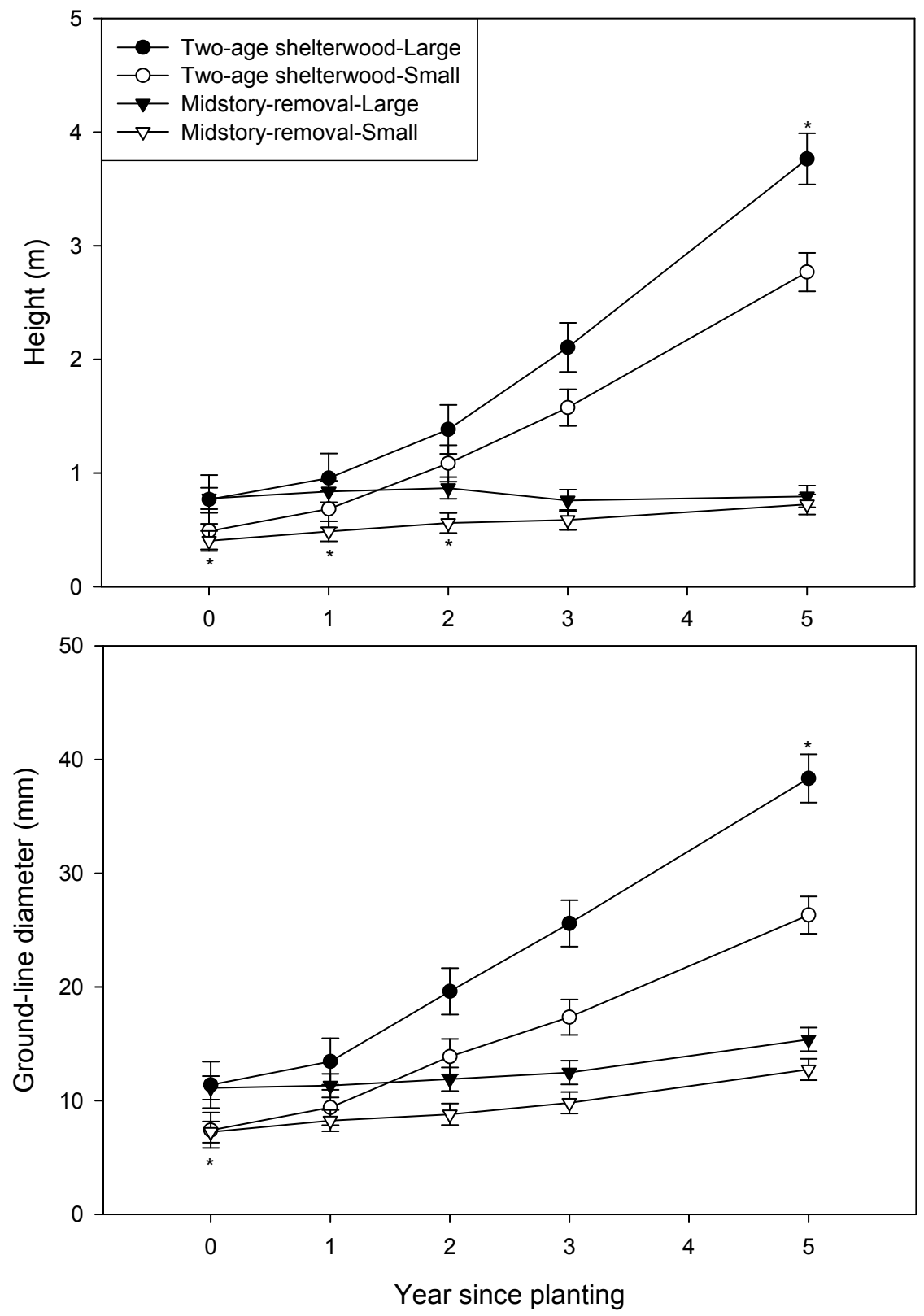
Height differences between size classes were significant for years 0,1 , and 2 in the midstory-removal treatment, but differences were not detected in years 3 or 5. GLD differences between size classes in the midstory-removal treatment were significant only for the year of planting. In the two-age shelterwood treatment, trees in the Large size class had similar GLD by year 2 and similar height by year 3 compared to Small size class trees in year 5. Seedling size class did not affect fifth year survival $(\mathrm{F}=1.6, \mathrm{df}=4, P=0.28)$, and interactions between size and treatment were not significant $(\mathrm{F}=0.6, \mathrm{df}=4, P=0.50)$.

By the fifth year after planting, 28 percent of living trees in the two-age shelterwood developed chestnut blight compared to 13 percent in the midstory-removal (Table 3); however, the overall effect of silvicultural treatment was not significant $(\mathrm{F}=5.3 \mathrm{df}=2, P=0.15)$.

Table 3. Least-squares means for percent of trees with blight. Standard errors are in parenthesis. Means followed by the same lowercase letter indicate differences between silvicultural treatments within and among years are not significant. Means followed by the same uppercase letters indicate differences among years across silvicultural treatments are not significant. Live trees and trees dead for less than one year were examined for blight.

\begin{tabular}{ccccc}
\hline $\begin{array}{c}\text { Year after } \\
\text { planting }\end{array}$ & $\begin{array}{c}\text { Two-age } \\
\text { shelterwood }\end{array}$ & Midstory & $\begin{array}{c}\text { Across } \\
\text { treatments }\end{array}$ & $\begin{array}{c}\text { Number of trees } \\
\text { examined for blight }\end{array}$ \\
\hline 1 & $0(3) \mathrm{b}$ & $1(3) \mathrm{b}$ & $0(2) \mathrm{C}$ & 213 \\
2 & $10(3) \mathrm{b}$ & $11(3) \mathrm{a}, \mathrm{b}$ & $11(2) \mathrm{B}$ & 181 \\
3 & $15(3) \mathrm{a}, \mathrm{b}$ & $9(3) \mathrm{b}$ & $12(2) \mathrm{A}, \mathrm{B}$ & 169 \\
5 & $28(3) \mathrm{a}$ & $13(3) \mathrm{a}, \mathrm{b}$ & $21(2) \mathrm{A}$ & 160 \\
\hline
\end{tabular}

The effect of year was significant $(\mathrm{F}=14.9, \mathrm{df}=12, P=0.01) ; 21$ percent of trees developed blight by year 5 . Trees had significantly more blight in year 2 compared to year 1 , and they had more blight by year 5 than in year 2. The interaction of year and treatment was nearing significance $(\mathrm{F}=3.1$, $\mathrm{df}=12, P=0.07)$. The EBLUPS for the random levels were not significantly different than zero, indicating that stand and stand by treatment interaction effects on blight development were minimal.

Trees with blight did not differ in height $(\mathrm{F}=0.2$, adjusted $\mathrm{df}=6, P=0.67)$, and there was no interaction between treatment and blight on height $(\mathrm{F}=0.05$, adjusted $\mathrm{df}=5, P=0.83)$. There was a significant interaction for height between blight and year $(\mathrm{F}=3.0$, adjusted $\mathrm{df}=365, P=0.03)$, but the comparisons among the least-squares means showed no differences in height between trees with and without blight for any year.

By the second, third, and fifth year, 79, 77, and 74 percent of trees were free-to-grow, respectively, in the two-age shelterwood stand. Free-to-grow status did not have a significant overall effect on height $(\mathrm{F}=9.5, \mathrm{df}=2, P=0.09)$ or GLD growth $(\mathrm{F}=9.8, \mathrm{df}=2, P=0.09)$, but the interaction between year and free-to-grow status was significant for height $(\mathrm{F}=23.6, \mathrm{df}=150, P<0.01)$ and GLD $(\mathrm{F}=26.4 \mathrm{df}=150, P<0.01)$. Free-to-grow trees were $1.53 \mathrm{~m}$ taller and $14.5 \mathrm{~mm}$ larger in GLD than overtopped trees by year 5 (Table 4). Height differences between free-to-grow trees and overtopped trees did not emerge until year 5, and GLD differences did not emerge until year 3. 
Table 4. Height and ground-line diameter least-squares mean differences between American chestnut trees that were free-to-grow and overtopped for 2, 3, and 5 years after planting. Means followed by the same letter indicate differences were not significant between free-to-grow and overtopped trees within and among years for each growth variable.

\begin{tabular}{ccccc}
\hline Year after & \multicolumn{2}{c}{ Height $(\mathbf{m})$} & \multicolumn{2}{c}{ Ground-line diameter $(\mathbf{m m})$} \\
\cline { 2 - 5 } planting & Free-to-grow & Overtopped & Free-to-grow & Overtopped \\
\hline 2 & $1.08 \mathrm{~d}$ & $1.24 \mathrm{~d}$ & $15.2 \mathrm{c}$ & $16.3 \mathrm{c}$ \\
3 & $1.80 \mathrm{~b}, \mathrm{c}$ & $1.44 \mathrm{c}, \mathrm{d}$ & $21.1 \mathrm{~b}$ & $16.3 \mathrm{c}$ \\
5 & $3.52 \mathrm{a}$ & $1.99 \mathrm{~b}$ & $34.5 \mathrm{a}$ & $20.0 \mathrm{~b}$ \\
\hline
\end{tabular}

The EBLUPS for each random stand level were not significantly different than zero, indicating that stand effects on free-to-grow status were minimal.

\section{Discussion}

Chestnuts were capable of fast growth under high-light conditions and low canopy cover of the two-age shelterwood stand, growing on average approximately $0.51 \mathrm{~m}$ in height and $4.3 \mathrm{~mm}$ in GLD per year. Other studies found that American chestnut maximizes photosynthesis under high-light conditions similar to other shade intolerant species [17,41], and has high growth rates following release from competition [42]. We suspect that American chestnut may be more competitive compared to other Fagaceae species on medium- to high-quality sites (site index $Q$. rubra $>22.9 \mathrm{~m}$, base age 50) in even-aged regeneration harvests. For example, Oswalt and others [43] found that northern red oak grew $0.40 \mathrm{~m}$ in height and $3 \mathrm{~mm}$ in GLD after two years in a two-age shelterwood harvest in the Gulf Coastal Plain. Similarly, northern red oaks planted in the same experimental forest as this study averaged less than $0.30 \mathrm{~m}$ in height growth per year after 11 years in clearcuts [44]. High-quality oak nursery seedlings planted on high-quality sites in western North Carolina regenerated using shelterwood or clearcut methods only grew $0.09 \mathrm{~m}$ per year in height and $<3 \mathrm{~mm}$ per year in GLD [45]. Other studies have found that American chestnut was the most competitive species, compared to other hardwoods, in adaptability to changes in light and nutrient resources [18] and in average growth rates after planting [46].

The fast growth of chestnuts and high percent of seedlings that were free-to-grow in our study may have been partially related to herbicide treatments for competition that were implemented at planting and three years after planting. Chestnut may not have been as competitive as natural vegetation on sites without aggressive treatment of competition. We conducted a post-hoc measurement of five-year height of dominant yellow-poplar saplings that were within the two-age treatment areas but outside of the planting areas that received the herbicide control at year 3. This competing vegetation averaged $4.00 \mathrm{~m}$ in height across all stands, which was $0.76 \mathrm{~m}$ taller than the average of the planted chestnuts. In the xeric stand, 66 percent of chestnuts were larger than the adjacent untreated competition, but none of the chestnuts were larger in height than the untreated vegetation in the mesic and subxeric stands. Based on this information, the height and percent of free-to-grow chestnuts may be greatly reduced if third year competition control was not implemented in the mesic and subxeric stand, but competitive status would not have been greatly affected on the most xeric site. Despite the two competition control 
measures conducted in this study, approximately 25 percent of trees were still suppressed after 5 years, indicating that managers should not expect competition control to benefit all planted chestnut seedlings, particularly the smallest seedlings planted. The differences in growth between free-to-grow and suppressed seedlings indicated the need to apply competition control to keep 75 percent of chestnuts planted growing at a fast rate. Five year-old suppressed seedlings had similar heights and GLDs compared to three year-old free-to-grow seedlings; thus, managers could gain 2 years in growth if trees can be kept free-to-grow. More research on the effects and interactions of competition control and site quality on growth is needed to empirically test these preliminary findings.

If managers choose to underplant in a treatment similar to the midstory-removal used in this study, they can expect to have the same height and GLD growth at year 5 in the midstory-removal treatment, as they would have in year 3 in the two-age shelterwood harvest; thus, managers can expect to lose two years of height and GLD growth for the first five years trees grow in a commercial two-age shelterwood harvest on similar stands in the southern Appalachians. GLD had greater growth relative to seedling size at planting compared to height in this treatment; trees grew 57 percent of their original GLD and 36 percent of their original height after five years. Root development is closely associated with GLD growth in chestnut and other Fagaceas species [24,47]. These results indicate that in the shade of a midstory-removal treatment, chestnut will continue to develop its root system at the expense of gaining height. These same trends are similar to those found in a two-year old field study [19] and in an outdoor shade-house study [17]. Despite the low levels of growth in the midstory-removal treatment, survival rates in this treatment indicate chestnuts will meet photosynthetic demands under an intact forest overstory canopy for at least five growing seasons, similar to previous studies [16,20]. Our results support the observations of Paillet [42], who hypothesized that chestnut efficiently uses limited light resources through recurrent root-collar sprouting and advantageous growth once released. We cannot predict how much longer planted seedlings will survive under the low-light environment of the midstory-removal, but native chestnuts live decades in forest understories [48,49].

Seedling quality at planting was not an a priori treatment in this study, but grading seedlings into the largest size class at planting would probably have benefitted chestnut growth in the two-age shelterwood stand. In contrast, grading seedlings would probably not have affected seedlings in the midstory-removal treatment. These results support a number of other studies that found seedling quality at planting affects field performance of Fagaceae species, summarized in Dey and others [50]. Range in seedling sizes at planting was substantial in this study $(0.08-0.98 \mathrm{~m}$ height, $3.6-19.0 \mathrm{~mm}$ GLD), so seedling grading would have been possible [47]. The mean size at planting in this study was below standards for other hardwood species [47,51,52], so the relatively good growth of seedlings in both grades was somewhat surprising. Our results indicate managers could gain two years of height growth and three years of GLD growth by culling Small seedlings before planting in the two-age shelterwood stand. Grading seedlings based on size would have increased efficiency of planting operations and probably would lead to less need for competition control. While these results should be interpreted with caution, as they were not part of our original design, seedling quality as a factor in American chestnut restoration probably has important implications [11,53].

No evidence of site type effects on growth or free-to-grow status was evident in this study, but lack of replication limited our interpretation of the site type gradient and its interactions with silvicultural treatment. Rhoades and others [15] found that the growth difference between seedlings planted on sites 
receiving the same two silvicultural treatments as tested in our study was less prevalent on xeric sites. In this study, predicted survival did differ among the xeric and subxeric stands in the two-age shelterwood treatment. Without further replication, however, we cannot determine if these differences are due to true site quality differences or if there were unknown parameters disproportionally affecting survival in these two stands (e.g., poor planting practices, disease, insect defoliation).

Our results did not support previous findings that found blight disease was more prolific in open environments, compared to understory sites [21] and in seedlings with fast early growth [54], but our results are relatively preliminary. Although we did not find significant overall effects of silvicultural treatment on blight development, the 15 percent difference between the midstory-removal and two-age shelterwood treatments at year 5 would probably have biological significance to managers and plant breeders. Previous studies suggest that bio-control measures of blight such as hypovirulence will be easier to conduct in shaded environments, such as the midstory-removal, where growth is reduced due to less competition and lower light levels $[21,55]$. In contrast, blight-resistance testing of breeding lines, as is being done currently [11], should be conducted in mesic forests with an open forest canopy and competition control, where seedlings can achieve their best growth potential [13].

We did not detect a difference in overall height growth between seedlings with blight and seedlings without blight in any year, indicating that a response to the disease did not include a change in growth. Paillet [42] also found growth form between blighted and unblighted trees to be similar. The occurrence of new sprouts after blight infection is common [42], but in our study, 0 to 20 percent of trees in any given year had new sprouts as a result of blight. Blight did not kill many trees in this study, probably due to the frequent release of competition and lack of deer browse that will favor chestnut survival and natural blight control [13].

\section{Conclusions}

Based on our results and previous studies, the two-age shelterwood treatments would be the most efficacious method of establishment for American chestnut seedlings on similar sites to those in this study. However, midstory-removal treatments may provide appropriate planting areas if chestnut planting material becomes available prior to harvesting of potential planting sites. This treatment may be particularly desirable on federal lands where harvest operations can be delayed due to NEPA processes or extension allowed under contract due to unfavorable timber market conditions. We explored questions that deserve attention in future research that could impact operational approaches for chestnut restoration. Although not empirically tested, seedling grading and competition control to keep seedlings free-to-grow may decrease time needed to establish a competitive chestnut seedling, and would decrease associated costs and resources needed for successful restoration.

\section{Acknowledgments}

The authors thank The American Chestnut Foundation for providing the experimental material for this study. The authors also acknowledge Leila Pinchot, Pinchot Institute, and Charles Rhoades, USDA Forest Service for early reviews of this manuscript. Two anonymous reviews also greatly improved the manuscript. The staff of the Pisgah National Forest, particularly Ted Oprean, was instrumental in helping establish harvest areas and conducting herbicide treatments. Arnold Saxton, 
The University of Tennessee, provided statistical analysis advice for this manuscript. Data collection assistance by USDA Forest Service, Southern Research Station employees, Jacqui Adams, Kenny Frick, and Tracy Roof, was also greatly appreciated.

\section{Conflict of Interest}

The authors declare no conflict of interest.

\section{References}

1. Delcourt, H.R.; Delcourt, P.A. Late-quaternary vegetational dynamics and community stability reconsidered. Quat. Res. 1983, 19, 265-271.

2. Burnham, C.R. The restoration of the American chestnut. Am. Sci. 1988, 76, 478-487.

3. Russell, E.W.B. Pre-blight distribution of Castanea dentata (Marsh.) Borkh. Bull. Torrey Bot. Club 1987, 114, 183-190.

4. Hepting, G.H. Death of the American chestnut. J. For. Hist. 1974, 18, 60-67.

5. Ashe, W.W. Chestnut in Tennessee; Bulletin Number 10-B; Tennessee Geological Survey: Nashville, TN, USA, 1911.

6. Emerson, A.I.; Weed, C.M. Our Trees and How to Know Them; J. B. Lippincott Company: Philadelphia, PA, USA, 1908.

7. Anagnostakis, S.L. The pathogens and pests of chestnuts. Adv. Bot. Res. 1995, 21, 125-145.

8. Paillet, F.L. Chestnut: History and ecology of a transformed species. J. Biogeogr. 2002, 29, 1517-1530.

9. Anagnostakis, S.L. The effect of multiple importations of pests and pathogens on a native tree. Biol. Invasions 2001, 3, 245-254.

10. Burnham, C.R.; Rutter, P.A.; French, D.W. Breeding blight-resistant chestnuts. Plant Breed. Rev. 1986, 4, 347-397.

11. Clark, S.L.; Schlarbaum, S.E.; Saxton, A.M.; Hebard, F.V. Making history: Field testing of blight-resistant American chestnut (Castanea dentata) in the southern region. In Proceedings of the 17th Central Hardwood Forest Conference, Lexington, KY, USA, 5-7 April 2010; Fei, S., Lhotka, J.M., Stringer, J.W., Gottschalk, K.W., Miller, G.W., Eds.; USDA Forest Service: Newtown Square, PA, USA, 2011; pp. 656-657.

12. Jacobs, D.F. Toward development of silvical strategies for forest resoration of American chestnut (Castanea dentata) using blight-resistant hybrids. Biol. Conserv. 2007, 137, 497-506.

13. Griffin, G.J. Blight control and restoration of the American chestnut. J. For. 2000, 98, $22-27$.

14. Clark, S.L.; Schlarbaum, S.E.; Saxton, A.M.; Hebard, F.V.; Blanton, J.; Casey, D.; Crane, B.; MacFarlane, R.; Rodrigue, J.; Stelick, J. Lessons from the field: The first tests of restoration American chestnut (Castanea dentata) seedlings planted in the Southern Region. In Proceedings of the 16th Biennial Southern Silvicultural Research Conference, Charleston, SC, USA, 15-16 February 2011; Butner, J.R., Ed.; USDA Forest Service: Asheville, NC, USA, 2012; pp. 69-70.

15. Rhoades, C.; Loftis, D.; Lewis, J.; Clark, S. The influence of silvicultural treatments and site conditions on American chestnut (Castanea dentata) seedling establishment in eastern Kentucky, USA. For. Ecol. Manag. 2009, 258, 1211-1218. 
16. Joesting, H.M.; McCarthy, B.C.; Brown, K.J. The photosynthetic response of American chestnut seedlings to differing light conditions. Can. J. For. Res. 2007, 37, 1714-1722.

17. Wang, G.G.; Bauerle, W.L.; Mudder, B.T. Effects of light acclimation on the photosynthesis, growth, and biomass allocation in American chestnut (Castanea dentata) seedlings. For. Ecol. Manag. 2006, 226, 173-180.

18. Latham, R.E. Co-occurring tree species change rank in seedling performance with resources varied experimentally. Ecology 1992, 73, 2129-2144.

19. McCament, C.L.; McCarthy, B.C. Two-year response of American chestnut (Castanea dentata) seedlings to shelterwood harvesting and fire in a mixed-oak forest ecosystem. Can. J. For. Res. 2005, 35, 740-749.

20. McNab, W.H.; Patch, S.; Nutter, A.A. Early results from a pilot test of planting small American chestnut seedlings under a forest canopy. J. Am. Chestnut Found. 2003, 16, 32-41.

21. Griffin, G.J. Incidence of chestnut blight and survival of American chestnut in forest clear-cut and neighboring understory sites. Plant Dis. 1989, 73, 123-127.

22. Spetich, M.A.; Dey, D.C.; Johnson, P.S.; Graney, D.L. Competitive capacity of Quercus rubra L. planted in Arkansas Boston Mountains. For. Sci. 2002, 48, 504-517.

23. Schweitzer, C.J.; Dey, D.C. Forest structure, composition, and tree diversity response to a gradient of regeneration harvests in the mid-Cumberland Plateau escarpment region, USA. For. Ecol. Manag. 2011, 262, 1729-1741.

24. Clark, S.L.; Schweitzer, C.J.; Schlarbaum, S.E.; Dimov, L.D.; Hebard, F.V. Nursery quality and first-year response of American chestnut (Castanea dentata) seedlings planted in the southeastern United States. Tree Planters Notes 2009, 53, 13-21.

25. Loftis, D.L. A shelterwood method for regenerating red oak in the southern Appalachians. For. Sci. 1990, 36, 917-929.

26. Jones, C.; Griffin, G.J.; Elkins, J.R. Association of climatic stress with blight on Chinese chestnut in the eastern United States. Plant Dis. 1980, 64, 1001-1004.

27. United State Department of Agriculture; Forest Service. Land and Resource Management Plan, Cherokee National Forest; Management Bulletin 8-MB-114A; USDA Forest Service: Southern Region, Atlanta, GA, USA, 2004.

28. United State Department of Agriculture; Forest Service Southern Region. Land and Resource Management Plan, Jefferson National Forest; Management Bulletin R8-MB-115A; USDA Forest Service: Southern Region, Atlanta, GA, USA, 2004.

29. United State Department of Agriculture; Forest Service Southern Region. Land and Resource Management Plan for the Daniel Boone National Forest; Management Bulletin R8-MB-117A; USDA Forest Service: Southern Region, Atlanta, GA, USA, 2004.

30. United State Department of Agriculture; Forest Service Southern Region. Environmental Assessment, Upper Santeetlah Project. Cheoah Ranger District, Nantahala National Forest. USDA Forest Service Nantahala National Forest: Robbinsville, NC, USA. Available online: http://www.fs.fed.us/nepa/fs-usda-pop.php/?project=23585 (assessed on 10 August 2012).

31. Gravatt, G.F.; Gill, L.S. Chestnut Blight; United States Department of Agriculture Farmers Bulletin 1641; United States Government Printing Office: Washington, DC, USA, 1930. 
32. Braun, E.L. Deciduous Forests of Eastern North America; Blakiston Co.: Philadelphia, PA, USA, 1950.

33. Keever, C. Present composition of some stands of the former oak-chestnut forest in the Southern Blue Ridge Mountains. Ecology 1953, 34, 44-54.

34. Woods, F.W.; Shanks, R.E. Replacement of chestnut by other species in the Great Smoky Mountains National Park. Ecology 1959, 40, 349-361.

35. Beck, D.E. Management options for southern Appalachian hardwoods: The two-aged stand. In Proceedings of the Fourth Biennial Southern Silvicultural Research Conference, Atlanta, GA, USA, 4-6 November 1986; Phillips, D.R., Ed.; USDA Forest Service: Asheville, NC, USA, 1986; pp. $451-454$.

36. Griffin, G.J.; Elkins, J.R. Chestnut Blight. In Chestnut Blight, Other Endothia Diseases, and the Genus Endothia; Roane, M.K., Griffin, G.J., Elkins, J.R., Eds.; APS Press: St. Paul, MN, USA, 1986; pp. 1-26.

37. SAS Institute Inc. SAS/STAT User's Guide, Version 9, 2nd ed.; SAS Institute Inc.: Cary, NC, USA, 2009.

38. Littell, R.C.; Henry, P.R.; Ammerman, C.B. Statistical analysis of repeated measures data using SAS procedures. J. Anim. Sci. 1998, 76, 1216-1231.

39. Design and Analysis Web Guide. DAWG Web site. Available online: http://dawg.utk.edu/ (accessed on 15 June 2011).

40. Hebard, F.V. Backcross breeding program produces blight-resistant American chestnuts (Virginia). Ecol. Restor. 2001, 19, 252-254.

41. Joesting, H.M.; McCarthy, B.C.; Brown, K.J. Determining the shade tolerance of American chestnut using morphological and physiological leaf parameters. For. Ecol. Manag. 2009, 257, 280-286.

42. Paillet, F.L. Growth form and life histories of American chestnut and Allegheny and Ozark chinquapin at various North American sites. Bull. Torrey Bot. Club 1993, 120, 257-268.

43. Oswalt, C.M.; Clatterbuck, W.K.; Houston, A.E. Impacts of deer herbivory and visual grading on the early performance of high-quality oak planting stock in Tennessee, USA. For. Ecol. Manage. 2006, 229, 128-135.

44. Loftis, D.L. Northern Red Oak Performs Poorly in North Carolina Planting; Research Note SE-277; USDA Forest Service: Asheville, NC, USA, 1979.

45. Schuler, J.L.; Robison, D.J. Performance of northern red oak enrichment plantings in naturally regenerating Southern Appalachian hardwood stands. New For. 2010, 40, 119-130.

46. Jacobs, D.F.; Severeid, L.R. Dominance of interplanted American chestnut (Castanea dentata) in southwestern Wisconsin, USA. For. Ecol. Manag. 2004, 191, 111-120.

47. Clark, S.L.; Schlarbaum, S.E.; Kormanik, P.P. Visual grading and quality of 1-0 northern red oak seedlings. South. J. Appl. For. 2000, 24, 93-97.

48. Paillet, F.L. Growth form and ecology of American chestnut (Castanea dentate) sprout clones in northeastern Massachusetts. Bull. Torrey Bot. Club 1984, 111, 316-328.

49. Paillet, F.L. Character and distribution of American chestnut sprouts in southern New England woodlands. Bull. Torrey Bot. Club 1988, 115, 32-44. 
50. Dey, D.C.; Jacobs, D.F.; McNabb, K.; Miller, G.; Baldwin, V.; Foster, G. Artificial regeneration of major oak (Quercus) species in the eastern United States-A review of the literature. For. Sci. 2008, 54, 77-106.

51. Kormanik, P.P.; Kormanik, T.L.; Sung, S.J.S.; Zarnoch, S.J.; Possee, C. Artificial regeneration of multiple hardwood species to develop specific forest communities. In Proceedings of the 10th Biennial Southern Silvicultural Research Conference, Shreveport, LA, USA, 16-18 February 1999; Haywood, J.D., Ed.; USDA Forest Service: Asheville, NC, USA, 1999; pp. 132-135.

52. Johnson, P.S. Growing hardwood nursery stock for planting on forest sites with special reference to northern red oak. In Proceedings of the 1989 Northeastern Area Nurseryman's Conference, Peoria, IL, USA, 24-27 July 1989; Mason State Nursery: Mason County, IL, USA, 1989; pp. 46-62.

53. Clark, S.L.; Schlarbaum, S.E.; Saxton, A.M.; Hebard, F.V. Nursery performance of American and Chinese chestnuts and backcross generations in commercial tree nurseries. Forestry 2012, 85, 589-600.

54. Reynolds, D.L.; Burke, K.L. The effect of growth rate, age, and chestnut blight on American chestnut mortality. Castanea 2011, 76, 129-139.

55. Milgroom, M.G.; Cortesi, P. Biological control of chestnut blight with hypovirulence: A critical analysis. Ann. Rev. Phytopathol. 2004, 42, 311-338.

(C) 2012 by the authors; licensee MDPI, Basel, Switzerland. This article is an open access article distributed under the terms and conditions of the Creative Commons Attribution license (http://creativecommons.org/licenses/by/3.0/). 